\title{
Model Kesesuaian Lahan Berbasis Kerawanan Bencana Alam, Uji Coba: Kota Semarang
}

Land Suitability Model Based on Vulnerability to Natural Disasters,

Case Study: Semarang City

\author{
Imam Buchori ${ }^{1}$, Yuwono Ario Nugroho², Joko Susilo³, Dian Prasetyaning1, \\ Hadi Nugroho ${ }^{4}$
}

Diterima : 18 September 2013

Disetujui : 29 Oktober 2013

\begin{abstract}
Abstrak: Wilayah Indonesia rawan terhadap berbagai bencana alam, untuk itu, Undang-undang No 26/2007 tentang Penataan Ruang mengamanatkan mitigasi bencana sebagai aspek penting. Makalah ini bertujuan mengembangkan model analisis kesesuaian lahan yang menitikberatkan aspek kesesuaian fisik dan kerawanan bencana. Model berupa pembobotan berbasis raster-SIG (Sistem Inforamsi Geografis). Model diujicobakan di Kota Semarang dengan pertimbangan variasi topografi yang lengkap, mulai dari pesisir di sisi Utara dan perbukitan di sisi Selatan. Hasil aplikasi menunjukkan model cukup baik dalam menjelaskan kesesuaian lahan, yang terbagi dalam tiga kategori, yaitu keleluasaan pengembangan rendah, menengah dan tinggi. Validasi dengan membandingkan output model dengan kondisi riil di lapangan menunjukkan akurasi sebesar 91,25\%. Namun, sebelum digeneralisasi dan diaplikasikan, model perlu diuji di beberapa lokasi yang memiliki karakteristik sesuai kebutuhan uji coba model.
\end{abstract}

\section{Kata kunci: rawan bencana, keseuaian lahan, model keruangan}

Abstract: Indonesian regions are prone to natural disasters. For this, Law 26/2007 on Spatial Planning orders that disaster mitigation is an important. This paper aims at developing a spatial model for suitability analysis, mainly considering physical and disaster prone conditions. The model is a raster based-GIS weighted scoring model. The model is applied in Semarang City with the consideration has various topographical conditions, from flat in the North and hilly in the South.The application shows that the model is suitable in representing land suitability in three categories, i.e. low, medium, and high flexibility of development. The validation, done by comparing the model output and reality, shows that its accuracy is $91,25 \%$. However, to be widely generazed, the model needs to be tested more, by applying in other locations having criteria regarding the needs of the test.

Keywords: disaster prone, land suitability, spatial model

\footnotetext{
${ }^{1}$ Jurusan Perencanaan Wilayah dan Kota, Fakultas Teknik, Universitas Diponegoro

Jl. Prof Sudharto SH, Tembalang, Semarang 50275

${ }^{2}$ Kementrian Perindustrian, Jl. Gatot Subroto Kav 52-53, Jakarta Selatan 12950

${ }^{3}$ Pemerintah Kota Samarinda, Jl. Kesuma Bangsa 82, Samarinda 75121

${ }^{4}$ Program Studi Teknik Geologi, Fakultas Teknik, Universitas Diponegoro,

Jl. Prof Sudharto SH, Tembalang, Semarang 50275
} 


\section{Pendahuluan}

Indonesia merupakan negara yang memiliki potensi bencana alam cukup tinggi. Potensi bencana tersebut memerlukan upaya mitigasi yang tepat. Mitigasi adalah upaya jangka panjang dalam mengurangi dampak kejadian bencana, yang perlu dilakukan sebelum, pada saat maupun sesudah terjadinya bencana. Diantara ketiganya, persiapan sebelum terjadinya bencana adalah kunci untuk meminimalisir resiko kerugian (Schneid, 2001, Huq, 2007 dan Chen, 2012). Oleh karena itu, semakin baik perencanaan mitigasi bencana yang dipersiapkan maka akan semakin kecil resiko kerusakan yang terjadi. Strategi meminimalisir resiko tersebut dapat berupa upaya menghindari dampak secara langsung, mengurangi dampak dengan memodifikasi lokasi (berpindah pada kawasan dengan dampak yang lebih sedikit), mengurangi dampak dengan memodifikasi desain, dan mengganti kerugian akibat bencana (Randolph, 2004).

Salah satu upaya mitigasi bencana adalah melalui penataan ruang berbasis mitigasi bencana. Hal ini sesuai dengan amanat Undang-undang No 26 tahun 2007 tentang Penataan Ruang yang menyatakan bahwa perencanaan tata ruang berbasis mitigasi bencana diperlukan sebagai upaya meningkatkan keselamatan dan kenyamanan kehidupan dan penghidupan. Perencanaan tata ruang meliputi rencana struktur ruang dan rencana pola ruang. Rencana struktur ruang mengatur sistem pusat-pusat permukiman dan jaringan prasarana dan sarana, sedangkan pola ruang mengatur peruntukan ruang untuk fungsi lindung dan budidaya. Karena mengatur peruntukan fungsi ruang maka rencana pola ruang secara prinsip juga mencakup aspek perencanaan tata guna lahan.

Aspek kesesuaian lahan harus menjadi pertimbangan utama di dalam menyusun rencana tata guna lahan. Peruntukan lahan yang tidak mempertimbangkan aspek mitigasi bencana akan menimbulkan kerentanan (vulnerability) bagi berbagai aktivitas yang ada di dalamnya. Kerentanan ini pada akhirnya akan berpengaruh pada produktivitas dan kinerja aktivitas-aktivitas tersebut. Sebaliknya, peruntukan lahan yang sesuai dengan daya dukung fisik dan lingkungan akan lebih menjamin keberlangsungan aktivitas yang ada.

Berdasarkan pertimbangan di atas, penelitian ini bertujuan untuk mengembangkan model keruangan untuk menilai kesesuaian lahan suatu wilayah, dengan menitikberatkan pada aspek kesesuaian fisik dan kerawanan terhadap bencana. Beberapa penelitian terdahulu menunjukkan bahwa model keruangan berbasis Sistem Informasi Geografis (SIG) sangat efektif dalam melakukan analisis keruangan terkait kerawanan bencana (lihat misalnya Lan, 2004, Alparslan, 2008, Gupta, 2008 dan Kamp, 2008). Oleh karena itu, model ini akan menggunakan SIG sebagai alat bantu utama dengan pertimbangan kemampuannya dalam melakukan analisis keruangan secara mudah, cepat dan akurat.

Untuk memastikan bahwa model yang dikembangan dapat diaplikasikan dengan baik, model tersebut diujicobakan di Kota Semarang. Kota Semarang dipilih karena memiliki morfologi yang bervariasi, yaitu kawasan pesisir di sisi Utara dan kawasan berbukit di sisi Selatan. Kondisi ini menyebabkan Kota Semarang menyimpan cukup banyak potensi bencana alam. Sebagai contoh, bencana banjir sering terjadi di Kota Semarang karena kondisi topografi yang datar di sisi Utara, sistem drainase yang buruk, serta penurunan tanah yang semakin cepat dari tahun ke tahun. Kondisi topografi yang berbukit-bukit juga menyimpan potensi tanah longsor. Selain itu, letak Kota Semarang di pesisir juga berpotensi tsunami jika suatu saat terjadi gempa. 


\section{Pengembangan Model}

\section{Penentuan Variabel}

Pengembangan model disini mengikuti tahapan pengembangan model keruangan yang meliputi langkah-langkah sebagai berikut (ESRI, 1997): menentukan variabel (kriteria) untuk analisis, menentukan kebutuhan data, menentukan operasi analisis dalam GIS akan dilakukan, menyiapkan data, menyusun model, menjalankan model, menganalisis hasil, dan memperbaiki model jika diperlukan. Penentuan variabel model dilakukan dengan mengkaji berbagai literatur dan beberapa model sejenis yang pernah dikembangkan sebelumnya.

Model keruangan dalam penelitian ini telah mengalami beberapa kali perubahan dan perbaikan. Model ini pertama kali dikembangkan dalam penelitian yang dibiayai oleh Dana Hibah Kompetitif fakultas Teknik UNDIP pada tahun 2008 oleh Buchori dkk. Selanjutnya, model dikembangkan kembali secara khusus untuk kawasan pesisir dan diujicobakan pada kawasan pesisir Kota Semarang dalam Tugas Akhir S1 PWK FT UNDIP oleh Nugroho (2008). Akhirnya, model diperbaiki kembali dan diaplikasikan untuk keseluruhan Kota Semarang pada tahun 2012, yang hasilnya dituliskan dalam makalah ini.

Mengacu Permen PU No.20/PRT/M/2007 tentang pedoman teknik analisis aspek fisik dan lingkungan dalam penyusunan rencana tata ruang,variable yang dapat digunakan dalam penilaian tingkat kesesuaian lahan berupa klimatologi, topografi, geologi, hidrologi, jenis tanah, potensi bencana alam, penggunaan lahan, kebijakan pemerintah hingga variabel yang pernah digunakan pada studi yang pernah dilakukan sebelumnya. Sedangkan Keputusan Presiden (Keppres) no 32/1997 tentang Pengelolaan Kawasan Lindung menyatakan bahwa kawasan hutan lindung, lahan gambut, kawasan resapan air adalah termasuk kawasan lindung bagi kawasan di belakangnya (hinterland), sedangkan sempadan sungai, danau, mata air dan pantai adalah termasuk kawasan lindung yang memberikan perlindungan setempat. Kawasan lain yang termasuk dalam kawasan lindung adalah kawasan suaka alam dan cagar budaya, dan kawasan rawan bencana alam. Keppres tersebut juga menyiratkan bahwa penetapan kawasan lindung dan budidaya melibatkan tiga variabel utama, yaitu kemiringan lahan, sensitivitas tanah dan curah hujan. Selain itu, pengembangan lahan juga harus memperhatikan kondisi fisik lahan, kualitas tanah dan ketersediaan air (Buchori, 2005).

Memperhatikan hal di atas, variabel dalam model ini akan dikelompokkan ke dalam dua jenis, yaitu variabel fisik alam dan variabel kerawanan bencana. Variabel fisik alam adalah variabel yang terkait dengan karakteristik geologi lingkungan dari wilayah tersebut. Variabel fisik alam meliputi meliputi berbagai kondisi fisik alamiah yang melekat pada suatu lokasi/area, misalnya kondisi topografi, morfologi, klimatologi, litologi, hidrologi, stratigrafi dan struktur tanah, dll. Adapun variabel kerawanan bencana adalah variabel yang menggambarkan aspek-aspek potensi kerawanan di suatu lokasi/area akibat bencana alam, seperti gempa bumi, longsor, terdampak letusan gunung berapi, banjir, dll.

Selanjutnya, variabel fisik alam dalam model ini dibatasi pada (1) kelerengan, (2) jenis tanah dan (3) kawasan lindung, yang berupa (3.a) zona konservasi air tanah, (3.b) sebaran kawasan lindung, (3.c) sempadan sungai dan (3.d) sempadan pantai. Sedangkan variabel kerawanan bencana yang akan dipergunakan dalam penelitian ini meliputi (1) potensi gempa bumi, (2) potensi gerakan tanah, (3) potensi landaan tsunami, (4) potensi penurunan permukaan tanah, (5) potensi tanah longsor, dan (6) potensi rawan banjir dan rob. Dalam hal ini, variabel potensi tanah longsor diambil dari model identifikasi kawasan rawan longsor oleh Buchori (2012). Pemilihan 
variabel-variabel tersebut didasarkan pada keberadaan data secara umum dan potensi bencana alam yang sering dijumpai di berbagai lokasi di Indonesia.

\section{Kebutuhan Data}

Semua data dalam model ini adalah data spasial yang berupa peta. Berdasarkan penentuan variabel di atas, peta-peta yang dibutuhkan dalam model ini adalah seperti terlihat pada Tabel 1.

Tabel 1 Variabel dan Kebutuhan Data

\begin{tabular}{|c|c|c|c|}
\hline No. & Variabel & Data & Keterangan \\
\hline \multicolumn{4}{|c|}{ Variabel fisik alam } \\
\hline 1. & Kelerengan & Peta Topografi & Menggambarkan kelerengan (slope) \\
\hline 2. & Jenis tanah/batuan & Peta Jenis Tanah & $\begin{array}{l}\text { Menggambarkan karakteristik tanah dan } \\
\text { batuan } \\
\text { Diolah dari Peta Geologi Teknik Lembar } \\
\text { Semarang-Magelang }\end{array}$ \\
\hline 3. & $\begin{array}{l}\text { Zona konservasi air } \\
\text { tanah }\end{array}$ & Peta Zona Air Tanah & $\begin{array}{l}\text { Menunjukkan penyebaran zona konservasi air } \\
\text { tanah } \\
\text { Diolah dari peta distribusi air tanah, dimana } \\
\text { peta distribusi air tanah terdiri atas berbagai } \\
\text { macam zona penggunaan dan distribusi air } \\
\text { tanah }\end{array}$ \\
\hline 4. & $\begin{array}{l}\text { Sebaran } \\
\text { lindung }\end{array}$ & Peta Kawasan Lindung & $\begin{array}{l}\text { Menggambarkan sebaran kawasan lindung } \\
\text { atau konservasi (hutan lindung, suaka alam } \\
\text { dan cagar budaya) } \\
\text { Diolah dari peta penggunaan lahan eksisting } \\
\text { dan peta rencana tata guna lahan }\end{array}$ \\
\hline 5. & Sempadan sungai & Peta Sempadan Sungai & $\begin{array}{l}\text { Berisi kawasan sempadan sungai } \\
\text { Dihasilkan dari buffer sungai, } 25 \text { meter di sisi } \\
\text { kiri dan kanan sungai }\end{array}$ \\
\hline 6. & Sempadan pantai & Peta Sempadan Pantai & $\begin{array}{l}\text { Berisi kawasan sempadan pantai } \\
\text { Dihasilkan dari buffer garis pantai, } 100 \text { meter } \\
\text { menuju daratan }\end{array}$ \\
\hline \multicolumn{4}{|c|}{ Variabel kerawanan bencana } \\
\hline 1. & Potensi gempa bumi & $\begin{array}{l}\text { Peta Potensi Gempa } \\
\text { Bumi }\end{array}$ & $\begin{array}{l}\text { Menggambarkan potensi terjadinya gempa } \\
\text { bumi }\end{array}$ \\
\hline 2. & $\begin{array}{l}\text { Kerentanan gerakan } \\
\text { tanah }\end{array}$ & $\begin{array}{l}\text { Peta Kerentanan } \\
\text { Gerakan Tanah }\end{array}$ & $\begin{array}{l}\text { Menunjukkan distribusi potensi terjadinya } \\
\text { gerakan tanah }\end{array}$ \\
\hline 3. & Potensi tsunami & $\begin{array}{l}\text { Peta Potensi Landaan } \\
\text { Tsunami } \\
\text { (ketinggian/dpl) }\end{array}$ & $\begin{array}{l}\text { Menunjukkan potensi terjadinya landaan } \\
\text { tsunami } \\
\text { Diolah dari peta ketinggian/DEM }\end{array}$ \\
\hline 4. & $\begin{array}{l}\text { Penurunan } \\
\text { tanah }\end{array}$ & $\begin{array}{l}\text { Peta Penurunan Muka } \\
\text { Tanah (cm/tahun) }\end{array}$ & $\begin{array}{l}\text { Menjelaskan besarnya penurunan permukaan } \\
\text { tanah }\end{array}$ \\
\hline 5. & $\begin{array}{l}\text { Potensi } \\
\text { longsor }\end{array}$ & $\begin{array}{l}\text { Peta potensi tanah } \\
\text { longsor }\end{array}$ & Berisi informasi kawasan rawan longsor \\
\hline 6. & Kawasan rob & Peta Kawasan Rob & $\begin{array}{l}\text { Menggambarkan sebaran lokasi } \\
\text { berpotensi rob }\end{array}$ \\
\hline 7 & $\begin{array}{l}\text { Potensi } \\
\text { genangan }\end{array}$ & $\begin{array}{l}\text { Peta potensi rawan } \\
\text { genangan }\end{array}$ & $\begin{array}{l}\text { Menggambarkan sebaran lokasi } \\
\text { berpotensi rawan genangan }\end{array}$ \\
\hline
\end{tabular}

Terkait sifat dan fungsinya, masing-masing variabel di atas dikelompokkan kembali berdasarkan perannya dalam analisis kesesuaian lahan menjadi dua kelompok, yaitu variabel pembobot dan variabel penyisih. Variabel pembobot adalah variabel yang dapat mempengaruhi kesesuaian lahan, tetapi tidak langsung menghilangkan fungsi kesesuaian. Dengan kata lain, variabel-variabel tersebut bersifat kendala, bukan limitasi. Adapun variabel penyisih adalah variabel yang 
bersifat limitasi sehingga memiliki keleluasaan rendah atau mungkin bahkan tidak dapat dikembangkan sama sekali.

Dalam model ini, variabel pembobot meliputi (1) kelerengan, (2) jenis tanah/batuan, (3) potensi rawan genangan, (4) zona konservasi air tanah, (5) potensi gempa bumi, (6) kerentanan gerakan tanah, (7) potensi landaan tsunami, (8) penurunan muka tanah, dan (9) potensi tanah longsor. Sedangkan variabel penyisih meliputi (1) kawasan lindung (termasuk sempadan sungai dan sempadan pantai), (2) kawasan longsor, dan (3) kawasan rob. Kawasan longsor sebagai variabel penyisih adalah kawasan yang sangat rawan longsor, sedangkan kawasan rawan longsor dengan kriteria sangat rendah, rendah dan menengah diperlakukan sebagai sebagai variabel penyisih.

\section{Model Analisis dan Klasifikasi Output}

Secara garis besar, model kesesuaian lahan ini terdiri dari dua sub model, yaitu sub model pembobotan yang melibatkan sembilan variabel pembobot dan sub model kriteria penyisih yang melibatkan empat variabel penyisih. Tahapan analisis dalam model adalah sebagaimana terlihat pada Gambar 1.

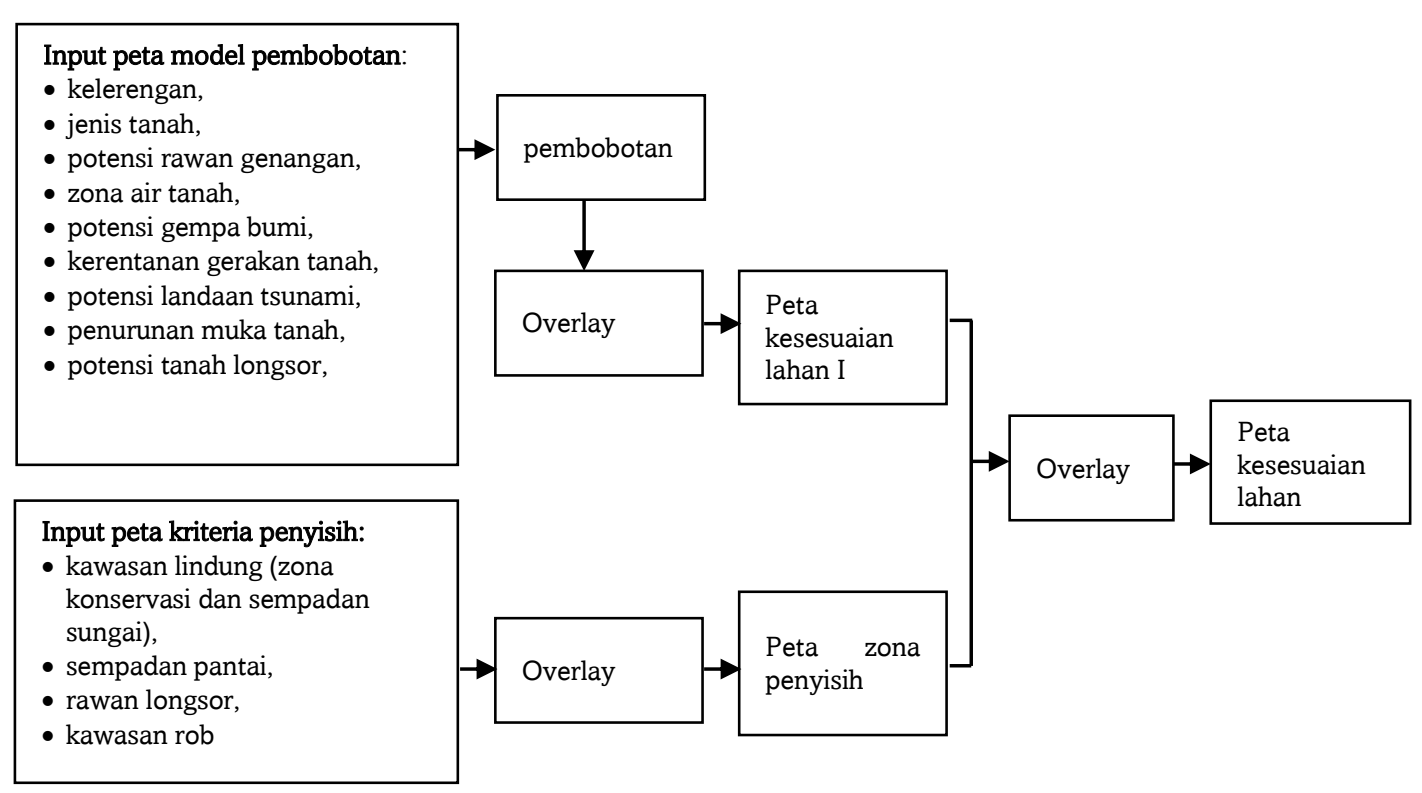

\section{Gambar 1 Konsep Model}

Sub model pembobotan berupa overlay sembilan peta sebagaimana Gambar 1 di atas. Proses pembobotan dilakukan berdasar nilai kriteria sebagaimana terlihat pada Tabel 2. Skor masing-masing kategori dalam variabel adalah kisaran nilai karakteristik dikalikan dengan bobot variabel. Skor tersebut selanjutnya dijumlahkan sebagai Nilai dari unit spasial, yang dihitung dengan menggunakan rumus sebagai berikut.

Nilai $=\sum$ skor masing-masing variable 
Dalam hal ini, karena SIG yang akan dipergunakan adalah berbasis raster, maka unit spasial tersebut adalah berupa pixel. Dengan demikian, nilai unit spasial tersebut sama dengan nilai pixel.

Tabel 2 Model Pembobotan

\begin{tabular}{|c|c|c|c|c|c|}
\hline No. & Variabel & Karakteristik (kisaran nilai) & & Bobot & Skor \\
\hline \multirow[t]{4}{*}{1.} & \multirow{4}{*}{$\begin{array}{l}\text { Kelerengan (peta topografi, diolah } \\
\text { menjadi peta kelerengan) }\end{array}$} & Datar $(0-2 \%)$ & \multirow[t]{4}{*}{4} & \multirow[t]{4}{*}{4} & 16 \\
\hline & & Landai $(2-15 \%)$ & & & 12 \\
\hline & & Terjal $(15-25 \%)$ & & & \\
\hline & & Sangat terjal $(>25 \%)$ & & & \\
\hline \multirow[t]{4}{*}{2.} & \multirow[t]{4}{*}{ Jenis tanah/batuan (peta jenis tanah) } & Keras & \multirow[t]{4}{*}{4} & \multirow[t]{4}{*}{4} & 16 \\
\hline & & Sedang & & & 12 \\
\hline & & Lunak & & & \\
\hline & & Sangat lunak & & & \\
\hline \multirow[t]{2}{*}{3.} & \multirow[t]{2}{*}{ Rawan genangan } & Aman & \multirow[t]{2}{*}{4} & \multirow[t]{2}{*}{4} & \multirow[t]{2}{*}{16} \\
\hline & & Rawan genangan & & & \\
\hline \multirow[t]{3}{*}{4.} & \multirow{3}{*}{$\begin{array}{l}\text { Zona konservasi air tanah (peta zona } \\
\text { produktivitasair tanah) }\end{array}$} & Daerah aman & \multirow[t]{3}{*}{4} & \multirow[t]{3}{*}{3} & \multirow[t]{3}{*}{12} \\
\hline & & $\begin{array}{l}\text { Daerah rawan (termasuk daerah } \\
\text { imbuhan) }\end{array}$ & & & \\
\hline & & Daerah kritis dan rusak & & & \\
\hline \multirow[t]{4}{*}{5.} & \multirow{4}{*}{$\begin{array}{l}\text { Potensi gempa bumi (peta potensi } \\
\text { gempa bumi) }\end{array}$} & $<5$ (skala Richter) & \multirow[t]{4}{*}{4} & \multirow[t]{4}{*}{4} & 16 \\
\hline & & $5-6$ & & & 12 \\
\hline & & $6-6,5$ & & & \\
\hline & & $>6,5$ & & & \\
\hline \multirow[t]{2}{*}{6.} & Kerentanan gerakan tanah (peta & Sangat rendah & \multirow[t]{2}{*}{4} & \multirow[t]{2}{*}{4} & 16 \\
\hline & kerentanan gerakan tanah) & $\begin{array}{l}\text { Rendah } \\
\text { Menengah }\end{array}$ & & & 12 \\
\hline \multirow[t]{4}{*}{7.} & \multirow{4}{*}{$\begin{array}{l}\text { Potensi tsunami (peta potensi landaan } \\
\text { tsunami-ketinggian/dpl) }\end{array}$} & $0-2 \mathrm{~m}$ & \multirow[t]{4}{*}{4} & \multirow[t]{4}{*}{2} & \multirow[t]{4}{*}{8} \\
\hline & & $2-5 m$ & & & \\
\hline & & $5-15 m$ & & & \\
\hline & & $>15 \mathrm{~m}$ & & & \\
\hline \multirow[t]{4}{*}{8.} & Penurunan permukaan tanah (Peta & 0 & 4 & 2 & 8 \\
\hline & penurunan muka tanah-cm/tahun) & $1-3$ & & & \\
\hline & & $3-6$ & & & \\
\hline & & $>6$ & & & \\
\hline 9. & Potensi Longsor (peta potensi tanah & Sangat rendah & 4 & 4 & 16 \\
\hline & lonsor) & Rendah & & & 12 \\
\hline & & Menengah & & & \\
\hline
\end{tabular}

Sumber: Analisis Penyusun, terinspirasi dari Kepmentan no. 837/1980

Hasil sub model pembobotan adalah Peta Kesesuaian Lahan 1. Selanjutnya, setiap unit spasial dalam peta tersebut diklasifikasi menjadi 3 kelas kesesuaian lahan berdasarkan nilai yang dimilikinya. Proses pengklasifikasian dilakukan mengacu klasifikasi keleluasaan pengembangan sebagaimana terlihat pada Tabel 3.

Pada tabel tersebut terdapat 3 kelas keleluasan pengembangan, yaitu tinggi, menengah dan rendah. Kelas keleluasaan pengembangan rendah merupakan kawasan yang tidak dapat dikembangkan karena biasanya termasuk dalam kawasan lindung, berdasar peraturan dan perundang-undangan yang berlaku. Kelas keleluasaan pengembangan menengah merupakan kawasan yang agak leluasa dikembangkan, sehingga pengembangannya memerlukan biaya yang lebih. Hal tersebut karena pengembangan kawasan pada kelas ini membutuhkan rekayasa fisik atau desain untuk mengurangi atau menghindari dampak dari faktor-faktor pembatas yang ada. Terakhir, kelas keleluasaan pengembangan tinggi merupakan kawasan dengan keleluasaan pengembangan yang tidak membutuhkan rekayasa fisik/desain secara berarti untuk pengembangannya. Kawasan pada kelas tersebut sangat leluasa dalam pengorganisasian ruang dan pemilihan penggunaan lahannya.

Sub model kriteria penyisih adalah gabungan variabel penyisih yang bersifat limitasi, dimana unit spasial yang terkena kriteria penyisih akan langsung dianggap 
sebagai kawasan dengan keleluasaan rendah. Proses dilakukan dengan overlay empat peta variabel penyisih, sehingga dihasilkan unit-unit spasial yang memiliki kelas keleluasaan tidak leluasa, sebagaimana terlihat pada Tabel 4. Peta yang dihasilkan disebut Peta Kriteria Penyisih.

Tabel 3. Klasifikasi Keleluasaan Pengembangan dan Penggunaan Lahan

\begin{tabular}{|c|c|c|c|}
\hline $\begin{array}{l}\text { Skor } \\
\text { Total }\end{array}$ & $\begin{array}{l}\text { Keleluasaan } \\
\text { Pengembangan }\end{array}$ & $\begin{array}{l}\text { Rekomendasi } \\
\text { Lahan }\end{array}$ & Keterangan \\
\hline $70-85$ & $\begin{array}{l}\text { Rendah/Tidak } \\
\text { Leluasa }\end{array}$ & $\begin{array}{l}\text { Kawasan lindung, bukan untuk } \\
\text { kawasan terbangun }\end{array}$ & $\begin{array}{l}\text { Tidak diperbolehkan sebagai } \\
\text { lahan terbagun. Kawasan hutan } \\
\text { mangrove dan sempadan sungai } \\
\text { dengan kemiringan lereng yang } \\
\text { tinggi. }\end{array}$ \\
\hline $85-100$ & Menengah & $\begin{array}{l}\text { Kawasan terbangun dengan } \\
\text { rekayasa fisik, diutamakan } \\
\text { untuk permukiman skala } \\
\text { terbatas atau aktivitas yang } \\
\text { dikelola oleh swasta, seperti } \\
\text { pertambakan, industri, dll. }\end{array}$ & $\begin{array}{l}\text { Lahan terbangun yang } \\
\text { membutuhkan rekayasa } \\
\text { fisik/desain secara intensif } \\
\text { sehingga biaya pembangunan di } \\
\text { kawasn ini cukup tinggi }\end{array}$ \\
\hline $100-120$ & Tinggi & $\begin{array}{l}\text { Kawasan terbangun dengan } \\
\text { kegiatan intensif (permukiman } \\
\text { skala besar, perdagangan dan } \\
\text { jasa, fasilitas umum, industri, } \\
\text { dll.) }\end{array}$ & $\begin{array}{l}\text { Tidak membutuhkan rekayasa } \\
\text { fisik/desain secara berarti, sangat } \\
\text { leluasa dalam pengorganisasian } \\
\text { ruang dan pemilihan penggunaan } \\
\text { lahan }\end{array}$ \\
\hline
\end{tabular}

Sumber: Anaisis Penyusun, 2012

Tabel 4. Variabel Kriteria Penyisih

\begin{tabular}{|c|c|c|c|}
\hline No. & Variabel & Keterangan & Kelas \\
\hline 1. & $\begin{array}{l}\text { Kawasan lindung/konservasi (peta } \\
\text { kawasan lindung dan sempadan } \\
\text { sungai) }\end{array}$ & $\begin{array}{l}\text { Berupa kawasan hutan lindung atau } \\
\text { suaka alam dan cagar budaya serta buffer } \\
\text { sejauh } 25 \text { meter di samping kanan dan } \\
\text { kiri sungai }\end{array}$ & $\begin{array}{l}\text { Tidak } \\
\text { leluasa }\end{array}$ \\
\hline 2. & $\begin{array}{l}\text { Sempadan pantai (peta sempadan } \\
\text { pantai) }\end{array}$ & $\begin{array}{l}\text { Berupa buffer } 100 \text { meter ke arah daratan } \\
\text { dari genangan pasang tertinggi }\end{array}$ & $\begin{array}{l}\text { Tidak } \\
\text { leluasa }\end{array}$ \\
\hline 3. & $\begin{array}{l}\text { Rawan longsor } \text { (peta rawan } \\
\text { longsor) }\end{array}$ & $\begin{array}{l}\text { Potensi longsor tinggi dan sangat tinggi } \\
\text { dan tidak dapat ditoleransi lagi }\end{array}$ & $\begin{array}{l}\text { Tidak } \\
\text { leluasa }\end{array}$ \\
\hline 4. & Banjir (peta kawasan rawan banjir) & $\begin{array}{l}\text { Dalam daerah genangan banjir periode } \geq \\
5 \text { tahunan }\end{array}$ & $\begin{array}{l}\text { Tidak } \\
\text { leluasa }\end{array}$ \\
\hline
\end{tabular}

Sumber: Analisis Penyusun, 2012

Tahap berikutnya adalah melakukan overlay antara Peta Kesesuaian Lahan 1 dengan Peta Kriteria Penyisih. Peta tersebut dinamakan Peta Kesesuaian Lahan yang sekaligus merupakan hasil akhir dari model pembobotan yang dilakukan. Peta tersebut kemudian diklasifikasi kembali berdasarkan kriteria keleluasaan pengembangan, sebagaimana tertuang dalam Tabel 3 di atas.

\section{Uji Coba Model}

\section{Aplikasi Model}

Aplikasi model bertujuan untuk mengetahui sejauhmana model yang telah disusun dapat bekerja, sehingga nantinya dapat diketahui kekurangan-kekurangan yang perlu diperbaiki. Model analisis keseuaian lahan dibangun menggunakan model builder, salah satu alat bantu analisis (tools) dalam ArcGIS. Model builder dipilih 
karena kemampuannya dalam menggambarkan proses analisis, sehingga analisis menjadi lebih efisien, efektif dan mudah dipahami. Hal tersebut karena proses overlay dalam model builder menggunakan konsep flow chart atau diagram alir yang mampu menjelaskan input, proses dan output. Dengan demikian, proses overlay tidak dilakukan satu per satu tetapi sekaligus pada beberapa peta. Gambar aplikasi secara keseluruhan model builder untuk model ini adalah sebagaimana terlihat pada Gambar 2. Sedangkan penjelasan per bagian/tahapan untuk masing-masing sub model akan dijelaskan pada paragraf berikut.

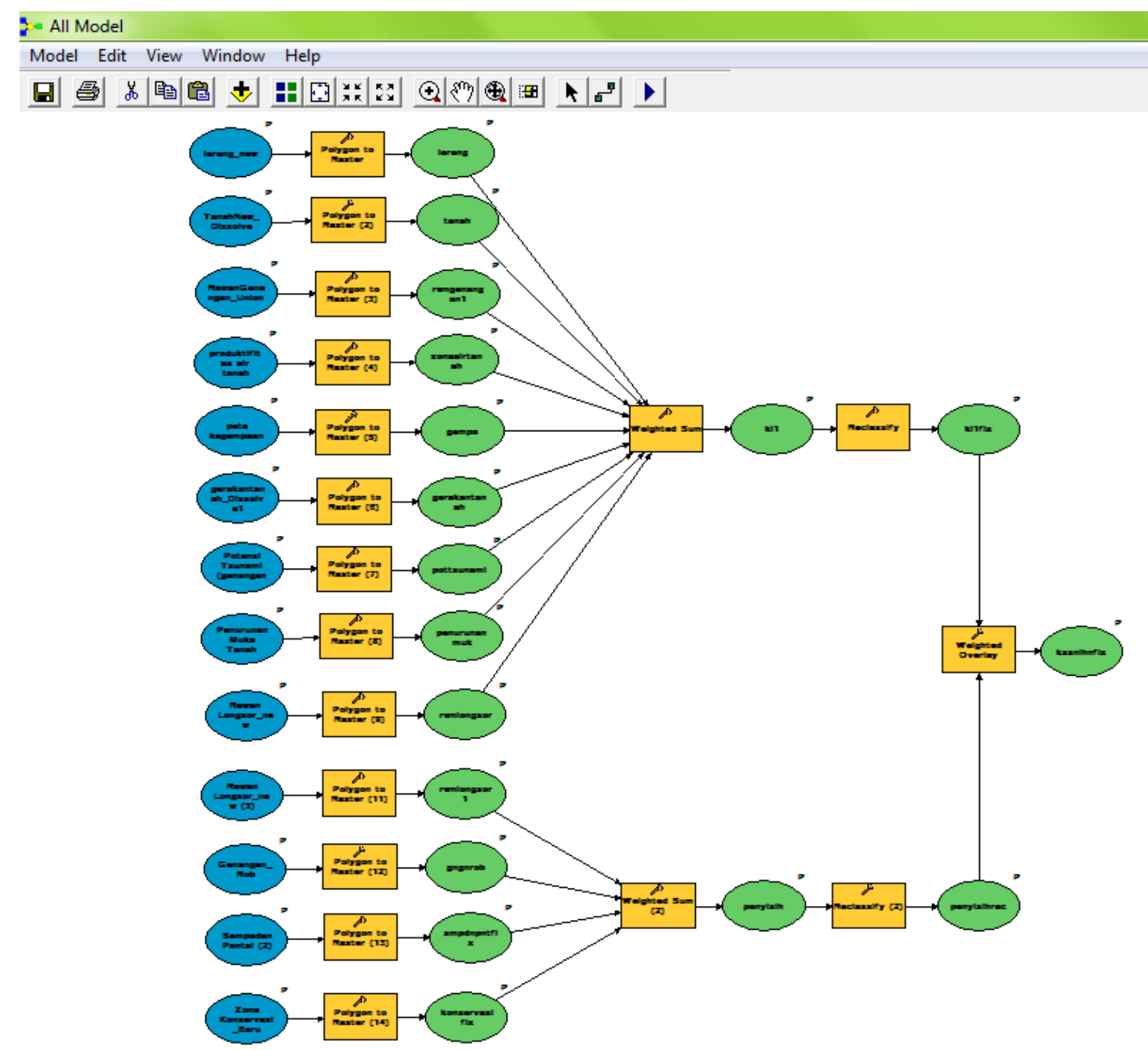

Sumber: Analisis Penyusun, 2012

\section{Gambar 2. Model Peta Kesesuaian Lahan}

Proses overlay pada sub model pembobotan dilakukan dengan menggunakan fungsi weighted sum, dimana data spasial (format *.shp) yang digunakan sebagai input terlebih dahulu dilengkapi dengan atribut keterangan dari masing-masing variabel. Dalam hal ini, data spasial yang berupa atribut total skor adalah hasil perkalian antara nilai dan bobot pada model pembobotan untuk menentuan kesesuaian lahan (lihat kembali Tabel 2). Dari format *.shp tersebut kemudian 
dilakukan konversi menjadi format grid, dimana nilai unit spasial (value field) merupakan jumlah skor akhir dari model pembobotan tersebut. Selanjutnya, variabel yang sudah diubah menjadi raster (grid) ditambahkan ke dalam kolom input raster.

Hasil analisis adalah sebuah peta berbasis raster dengan nilai pixel dalam bentang nilai yang panjang, sebagai hasil penjumlahan dari masing-masing skor di atas. Untuk itu, tahap berikutnya adalah melakukan klasifikasi ulang (reclassification) yang range-nya disesuaikan dengan range kelas interval masing-masing kelas kesesuaian, sebagaimana ditampilkan dalam Tabel 3 di atas. Hasil klasifikasi ulang ini adalah Peta Kesesuaian Lahan, sebagaimana terlihat pada Gambar 3.

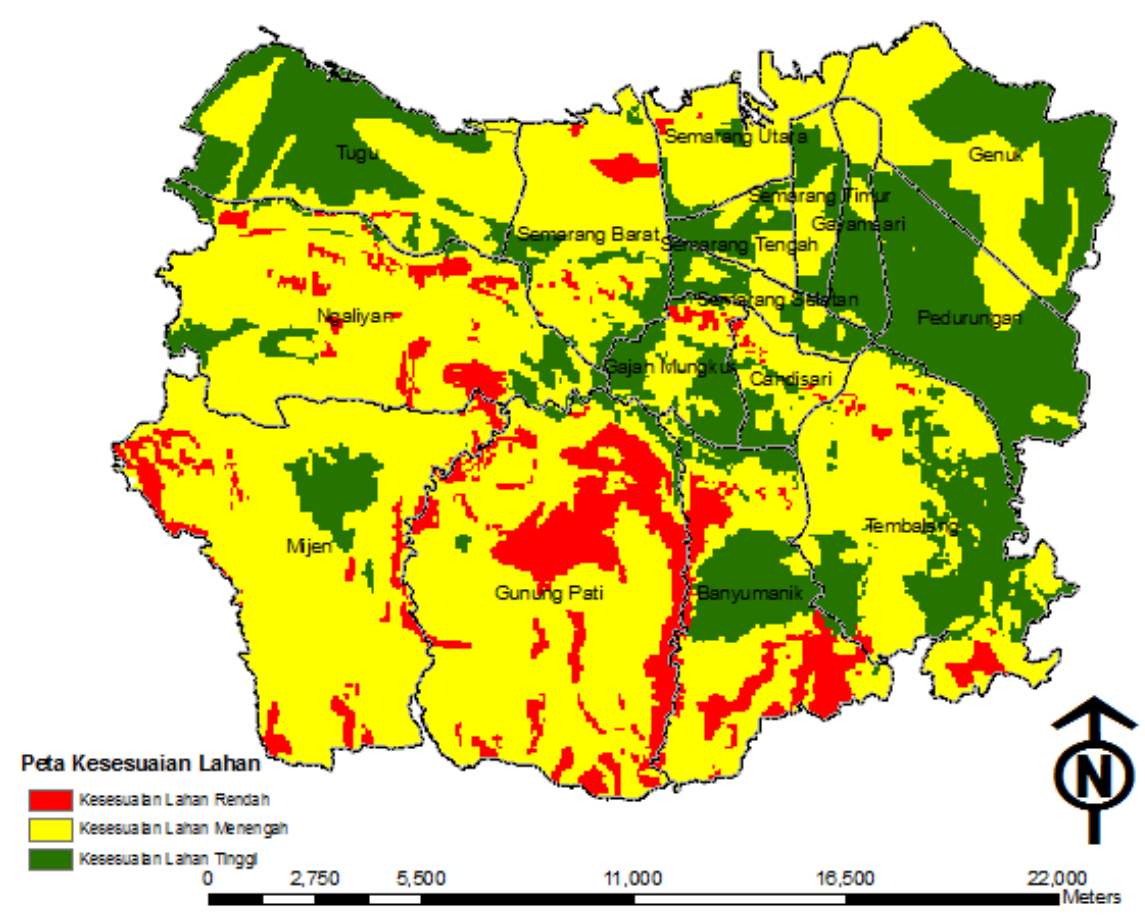

Sumber: Analisis Penyusun, 2012

Gambar 3. Peta Kesesuaian Lahan 1

Tahap selanjutnya adalah proses sub model kriteria penyisih untuk menghasilkan Peta Kriteria Penyisih. Proses overlay zona penyisih hampir sama dengan proses sub model pertama yaitu dengan menggunakan fungsi weighted sum, dimana input yang dipergunakan adalah peta dalam format *.shp. Masing-masing variabel penyisih dilengkapi dengan atribut berupa nilai 1 dan 0 . Nilai 1 menunjukkan wilayah yang berfungsi sebagai penyisih sedangkan nilai 0 menunjukkan wilayah yang bukan penyisih. Format *.shp masing-masing peta tersebut kemudian dikonversi menjadi format grid, dimana value field merupakan jumlah skor akhir dari model pembobotan tersebut. Selanjutnya, proses overlay dilakukan dengan menggunakan fungsi weighted sum. Setelah proses overlay, proses klasifikasi ulang dilakukan guna mengelompokkan unit spasial menjadi 2 kelas, yaitu kelas zona penyisih dan zona bukan penyisih (leluasa). Hasilnya adalah sebagimana terlihat pada Gambar 4.

Tahap selanjutnya, Peta Penyisih di-overlay dengan Peta Kesesuaian Lahan I untuk mengeliminasi area yang tidak layak dikembangkan. Hal tersebut karena 
semua kriteria yang termasuk dalam variabel kriteria penyisih memiliki kelayakan pengembangan yang rendah/tidak leluasa. Sama seperti sebelumnya, dalam proses overlay variabel kriteria penyisih ini, jika salah satu data variabel kriteria penyisih tidak tersedia, kurang atau tidak sesuai dengan syarat yang telah ditentukan dalam proses, maka proses analisis tidak dapat berjalan.

Hasil overlay tersebut menghasilkan peta dalam format raster yang kemudian perlu diklasifikasi kembali menjadi tiga kelas kesesuaian, dengan kriteria klasifikasi seperti pada Tabel 3 di atas. Setelah dilakukan klasifikasi kembali maka dihasilkan output akhir model, yaitu Peta Kesesuaian Lahan.

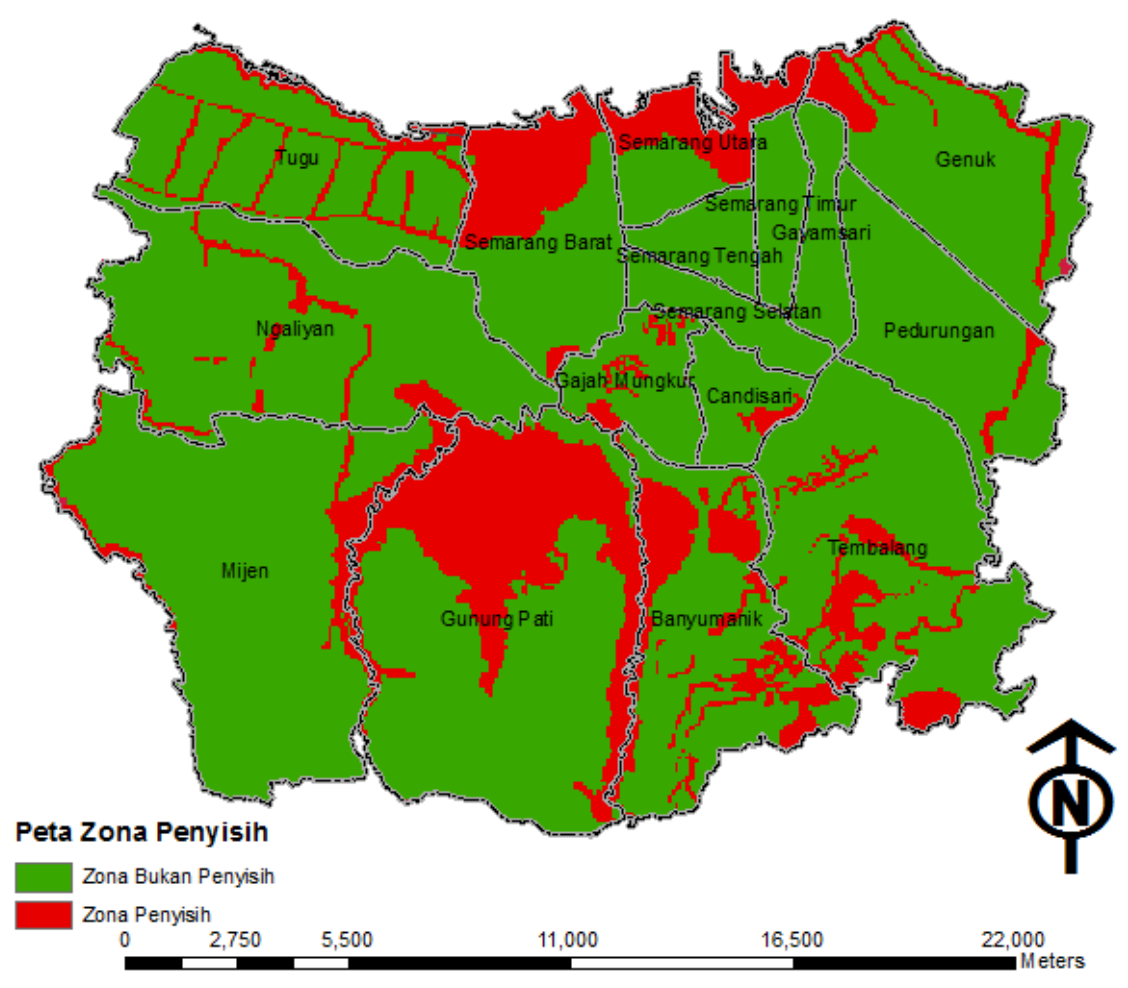

Sumber: Analisis Penyusun, 2012

\section{Gambar 4. Gambar Peta Zona Penyisih}

Tabel 5 menjelaskan luasan output model yang berupa luasan keleluasaan pengembangan untuk masing-masing kelas maka dapat diketahui bahwa dari luas total Kota Semarang, seluas $384 \mathrm{Km}^{2}$, lahan dengan keleluasaan tinggi, mempunyai sebesar $25,96 \%$ atau $99,536 \mathrm{Km}^{2}$. Lahan dengan keleluasaan menengah memiliki proporsi terbesar yaitu seluas $191,515 \mathrm{Km}^{2}$ atau $45,95 \%$. Sedangkan lahan yang tidak leluasa untuk dikembangkan (tingkat kelelulasaan rendah) memiliki luas sekitar $92,432 \mathrm{Km}^{2}$ atau hanya sekitar $24,10 \%$ dari luas Kota Semarang .Representasi hasil simulasi model tersebut dapat dilihat pada Gambar 5.

Sebagai catatan, aplikasi model kesesuaian lahan ini sangat ditentukan oleh kualitas data. Dalam hal ini, data harus valid dan merepresentasikan keadaan di lapangan, sehingga hasil aplikasi sesuai kondisi riil di lapangan. Oleh karena itu, data harus diperoleh dari institusi yang kredibel, atau jika perlu, divalidasi dengan menggunakan survei lapangan. 
Tabel 5 Luasan Output

\begin{tabular}{lll}
\hline Keleluasaan & Luas (Km2) & Keterangan \\
\hline Rendah & $92,432 \mathrm{Km} 2$ & $\begin{array}{l}\text { Kawasan yang direkomendasikan untuk tidak dikembangkan, } \\
\text { terlebih sebagai kawasan terbagun, karena berada pada kawasan } \\
\text { yang memiliki kendala fisik atau kendala pengembangan berdasar } \\
\text { aturan normatif, yaitu sebagai kawasan lindung. } \\
\text { Kenengah }\end{array} \quad 191,515 \mathrm{Km} 2 \quad \begin{array}{l}\text { Kawasan yang dapat dikembangkan, termasuk sebagai kawasan } \\
\text { terbangun, tetapi apabila akan dikembangkan memerlukan rekayasa } \\
\text { fisik/desain sehingga memerlukan biaya lebih, dibandingkan } \\
\text { kawasan yang memiliki keleluasaan tinggi. } \\
\text { Tidak membutuhan rekayasa fisik/desain secara berarti, sangat } \\
\text { leluasa dalam pengorganisasian ruang dan pemilihan penggunaan } \\
\text { lahan }\end{array}$ \\
\hline
\end{tabular}

Sumber: Analisis Penyusun, 2012

\section{Validasi}

Setelah output model diperoleh, validasi model dilakukan untuk menjustifikasi apakah model yang dihasilkan cukup valid sehingga dapat dilakukan generalisasi. Validasi dilakukan dengan membandingkan hasil output model dengan kondisi riil di lapangan. Untuk itu, ditentukan 80 titik di lapangan dengan menggunakan pola grid sebagai lokasi sampel. Selanjutnya, dilakukan visitasi lokasi di lapangan dan dilakukan penilaian kesesuaian. Dari hasil visitasi tersebut, terbukti $91,25 \%$ dari sampel memiliki kesesuaian antara output model dengan kondisi di lapangan. Hasil validasi output model tersebut adalah sebagaimana terlihat pada Gambar 6.






\section{Kesimpulan}

Dari pembahasan di atas dapat disimpulkan bahwa model dapat menjelaskan kesesuaian lahan di Kota Semarang sesuai tujuan yang diinginkan. Model mampu menjelaskan wilayah mana saja yang merupakan kawasan yang memiliki tingkat kesesuaian lahan dengan keleluasaan pengembangan tinggi, menengah dan rendah. Namun demikian perlu dicatat bahwa akurasi data sangat menentuan kualitas output.

Model kesesuaian lahan berbasis bencana alam ini dapat diterapkan pada lokasi lain yang memiliki karakteristik yang sama dengan pesisir Kota Semarang. Dalam pengembangan selanjutnya, kriteria-kriteria yang dipergunakan dapat dimodifikasi sehingga output model akan menjadi lebih baik. Modifikasi terhadap kriteria pembobot dan kriteria penyisih dapat disesuaikan dengan jenis dan tingkat bencana yang ada pada suatu wilayah. Semakin banyak jenis bencana yang ada maka akan semakin banyak pula kriteria yang harus dipergunakan. Untuk generalisasi model secara lebih luas, model perlu diuji kembali pada beberapa lokasi yang lain, khususnya dalam menentukan klasifikasi nilai untuk penentuan kawasan dengan keleluasaan tinggi, menengah dan rendah (Tabel 3).

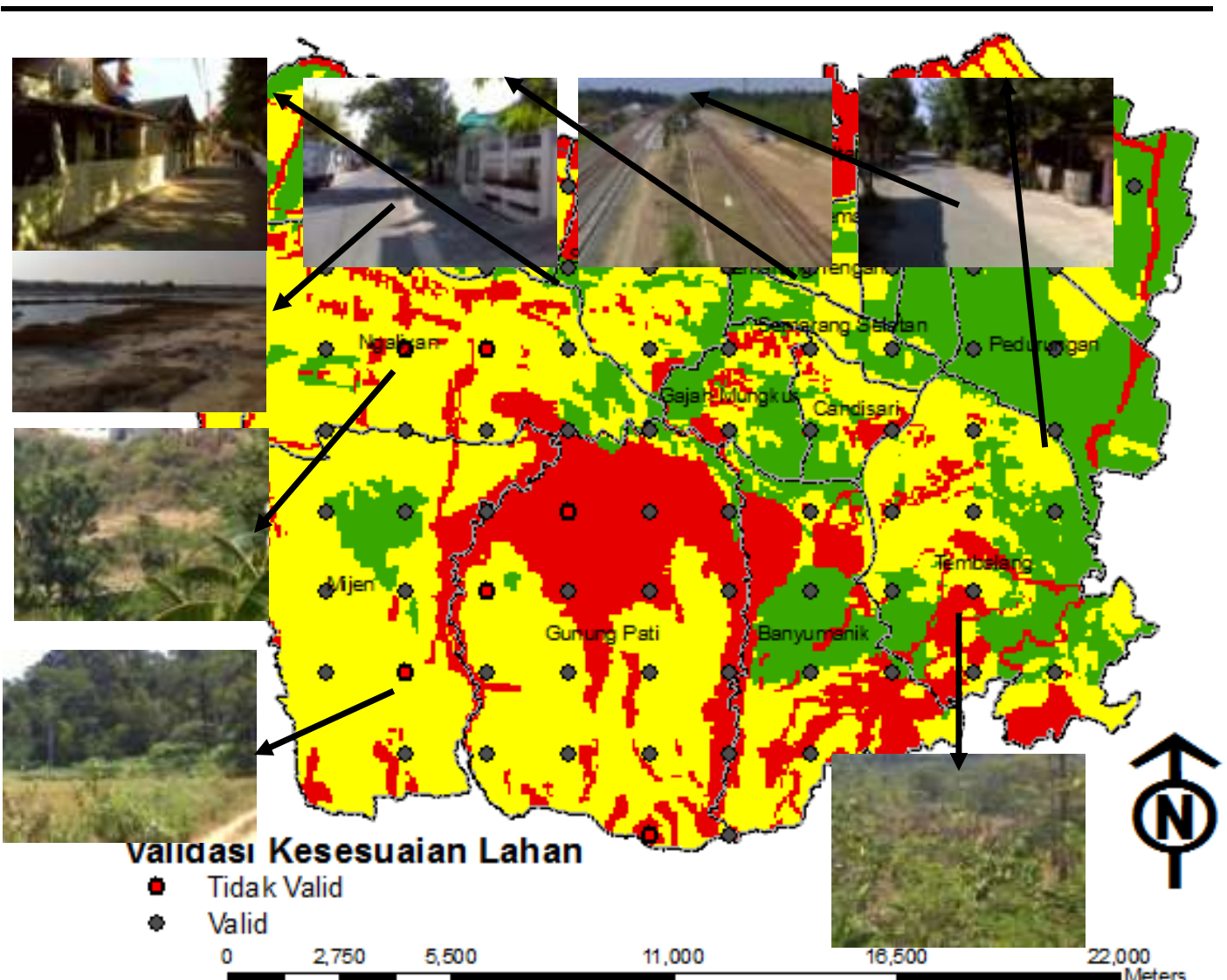

Sumber: Analisis Penyusun, 2013

\section{Gambar 6 Peta Validasi Model}

\section{Ucapan Terima Kasih}

Penelitian ini merupakan penyempurnaan dan pengolahan kembali pada tahun 2012, dari bagian penelitian induk berjudul "Upaya Mitigasi Bencana Dengan Pendekatan Penataan Ruang Berbasis Model Sistem Informasi Geografis (SIG), Studi 
Kasus: Kota Semarang" yang dibiayai oleh Hibah Penelitian Kompetitif DIPA Fakultas Teknik Universitas Diponegoro Tahun Anggaran 2008. Ucapan terima kasih saya sampaikan kepada Yudi Basuki, ST., MT., dan Sri Rahayu, ST, MT., atas masukannya sebagai anggota tim peneliti, yang sekaligus mengerjakan bagian lain di dalam penelitian tersebut

\section{Kepustakaan}

Alparslan, E., Ince, F., Erkan, B., Aydoner, C., Ozen, H., Donertas, A., Ergintav, S., Yagsan, F.S., Zaterogullari, A., Eroglu, I., Deger, M., Elalmis, H. and Ozkan, M. 2008. A GIS Model for Settlement Suitability Regarding Disaster Mitigation, A Case Study in Bolu Turkey. Engineering Geology, 96, 126-140.

Buchori, I. 2005. Developing a Spatial Information System for Regional Planning in Indonesia, a Case Study of the Rembang Regency. Vechta: HS Vechta.

Buchori, I. dan Susilo, J. 2012. Model Keruangan untuk Identifikasi Kawasan Rawan Longsor; Uji Coba: Kota Semarang. Tata Loka. 14/4, 282-294.

ESRI (Environmental System Research Institute). 1997. Getting to Know ArcView GIS. Redlands: ESRI.

Gupta, R.P., Kanungo, D.P., Arora, M.K. and Sarkar, S. 2008. Approaches for Comparative Evaluation of Raster GIS-based Landslide Susceptibility Zonation Maps. International Journal of Applied Earth Observation, 10, 330-341.

Huq, S., Kovats, S., Reid, H. and Satterthwaite, D. 2007. Editorial: Reducing Risks to Cities from Disaster and Climate Change, Environment \& Urbanization, 19/1, 3-16.

Kamp, U., Growley, B.J., Khattak, G.A. and Owen, L.A. 2008. GIS-based Landslide Susceptibility Mapping for the 2005 Kashmir Earthquake Region. Geomorphology, 101, 631-642.

Lan, H.X., Zhou, C.H., Wang, L.J., Zhang, H.Y. and Li, R.H. Landslide Hazard Spatial Analysis and Prediction Using GIS in the Xiaojiang Watersheed, Yunnan, China. Engineering Geology, 76, 109-128.

Randolph, J. 2004. Environmental Land Use Planning. Washington: Island Press.

Schneid. T.D. and Collins, L. 2001. Disaster Management and Preparedness. Boca Raton, Fla.: Lewis Publishers.

Nugroho, Y.A. 2008. Pengembangan Model Mitigasi Bencana Melalui Pengaturan Penggunaan Lahan dan Kaitannya Terhadap Tata Ruang, Studi Kasus Kota Semarang, Tugas Akhir S1 PWK FT UNDIP, Tidak Dipublikasikan, Semarang: JPWK FT UNDIP.

Chen, X., Kwan, M.P., Li, Q. and Chen, J. 2012. A Model for Evacuation Risk Assessment with Consideration of Pre- and Post-disaster Factors. Computers, Environment and Urban Systems, 36/3, 207-217.

-----. 2007. Undang-undang No. 26/2007 tentang Penataan Ruang.

-----. 1997. Keputusan Presiden (Keppres) No. 32/1997 tentang Pengelolaan Kawasan Lindung.

-----. 2008. Peraturan Menteri (Permen) PU No. 20/PRT/M/2007 tentang Modul Terapan Pedoman Teknis Analisis Aspek Fisik dan Lingkungan, Ekonomi, serta Sosial Budaya dalam Penyusunan Rencana Tata Ruang. Jakarta.

-----. 1980. Keputusan Menteri Pertanian (Kepmentan) No. 837/1980 tentang Kriteria dan Tata Cara Penetapan Hutan Lindung. 